\title{
The Potential of Green Bond Markets as Drivers of Change
}

\author{
Andra-Nicoleta $\mathrm{Mecu}^{1}$ \\ Florentina Chițu ${ }^{2}$ \\ Gheorghe Hurduzeu ${ }^{3}$
}

\begin{abstract}
The risks derived from climate change and the social inequalities of the economic model en-danger the continuity of society as we know it. The investment community is developing financial products in order to channel the environ-mental and social transition process, with green bonds and social bonds being key instruments to facilitate the change of model. In just a few years, investments made in assets that respect environmental sustainability, social responsibility and good management practices have in-creased from $12 \%$ to $42 \%$ of total investments made by investors around the world. The current paper it is intended to discuss the regulation and evolution of green bonds since its inception in 2007, globally and nationally, focusing on the principles of implementation, benefits and role of the COVID-19 pandemic in issuing green bonds.
\end{abstract}

Keywords: Climate Change, Green Bonds, Sustainability

JEL Classification: Q56, Q57, Q59

DOI: $10.24818 / \mathrm{REJ} / 2021 / 82 / 06$

\section{Introduction}

The 2015 Paris Agreement represented a strong commitment to the environment through which green bonds were promoted in the financial markets. In recent years, these new instruments have seen a significant increase in both issuers and issue volumes.

It is already known that one of the main concerns facing today's society is climate change, and experts around the world consider it essential to take measures to

\footnotetext{
${ }^{1}$ Bucharest University of Economic Studies, The Economics and International Business Doctoral School, Bucharest, Romania, andra.mecu@stud.ase.ro

2 Bucharest University of Economic Studies, The Economics and International Business Doctoral School, Bucharest, Romania, florentina.chitu@stud.ase.ro

3 Bucharest University of Economic Studies, Faculty of International Business and Economics Bucharest, Romania, gheorghe.hurduzeu@rei.ase.ro 
prevent the consequences of climate change, sea level rise, droughts, natural hazards, extreme weather events.

A sustainable solution to reduce harmful emissions can be to promote the use of renewable energies, in other words the use of those inexhaustible natural resources, such as sun, wind, biomass. To achieve this, it is imperative to raise awareness and encourage local authorities and countries to invest in projects, facilities and activities using these renewable sources to the detriment of nuclear or fossil fuels. However, this transition is a long and very costly process, which is why many companies need funding to carry out these projects.

Thus, there are various instruments for financing environmentally committed investments, one of which is known as "green bonds", and it can be decisive in the fight against climate change risks by their role of allocating funds to environmental investments and sustainable projects.

Green bonds are a new phenomenon in the area of finance. Its contribution to the dissemination of sustainable Development Goals and sustainable financing is significant. Since its emergence on the markets, developments have been fast, especially in recent years; but its relative share of the bond market remains low. In most cases, these issues took place in countries with advanced capital markets or with issuers with experience in fixed income.

The first green bond issue is considered to be the one made by the European Investment Bank (EIB) in 2007 (World Bank, 2015; Mathews and kidney, 2012; Baker et al., 2018). It was a bond issue known as Bond Climate awareness, structured with a term of five years for an amount of EUR 600 million, the profitability of which has been mentioned - through derivatives - in the evolution of the European sustainability Index FTSE4good environmental leaders Europe 40. The EIB has allocated funds to its programs to finance renewable energy and energy efficiency projects. Given the success of the first issue, in 2009 the EIB issued a new bond in the Swedish krona for an equivalent amount of EUR 240 million.

This issue set a precedent on the financial market in 2008, with the World Bank issuing its first green bond in Swedish krona for $\$ 440$ million. This was in response to the specific request of Scandinavian pension funds aimed at supporting projects with a positive environmental impact. This issue was the first of more than one hundred transactions in eighteen different currencies worth over $\$ 8,5$ billion that the institution has carried out since 2015 (World Bank, 2015). On the other hand, the International Financial Corporation (IFC) issued green bonds for the first time in 2010. In 2013, it issued two green bonds for three years, with one billion dollars, the highest issue on the market at the time. 
The growth of this market has led to initiatives by its main players to promote standards when issuing a green bond. In 2014, a group of investment banks under the coordination of the International Capital Markets Association (ICMA) published the „Green bond principles” (ICMA, 2018). These principles propose a set of voluntary guidelines for the characterization of green bonds and thus promote transparency and clarity in the definitions and processes of this market. They focus on the destination of funds to determine whether a bond is "green", not whether its issuer has environmental credentials.

The aim of this work is to deepen the current state of knowledge of green bonds, explaining what they are, how they work and to which European regulations are subject. Moreover, the opportunities created by the COVID-19 pandemic in the green bond market, as well as Romania's transition to a decarbonized and sustainable economy, are analyzed.

\section{Problem Statement}

A bond is a financial debt instrument that is issued to investors with a predetermined duration and interest rate. Investors in the bond market usually charge a fixed interest rate (coupon) over the life of the loan and recover the original investment on the maturity date. Therefore, bonds are generally referred to as „fixed-income securities". Bond issuers can be private companies, supranational institutions or public entities of all kinds (World Bank, 2015). A bond usually has a credit rating. The rating is a classification of the bonds by category according to the creditworthiness of the obligor or issuer in relation to their ability to repay the debt (or to meet their financial obligations) awarded by specialized entities known as „rating agencies” (Lopez and Sebastián, 2015).

On the basis of this definition of bonds, numerous instruments for green financing have emerged in order to meet climate risk management objectives. Green bonds are bonds that are ,issued to generate special capital to support projects related to the environment or climate change" (World Bank, 2015). This exclusive "specific use" of funds in environmentally sustainable investment distinguishes green bonds from other bonds, which is a key requirement for the bond to be qualified as environmentally sound, together with its verification and audit. Thus, when it comes to a green bond, in addition to assessing its financial characteristics such as the maturity, coupon, price or credit quality of the issuer, the "specific environmental objective" of the projects to be financed is also assessed OECD (2015), Green bonds mobilizing the debt capital markets for a low-carbon transition. The significant growth in the green bond market reflects how the financial sector prepares for climate risks (Clapp, 2018). However, the green bond market has not reached its full potential, as it is necessary to clarify the 
investment processes so that investors, banks, investment agents, asset managers and others can understand the characteristics of each green bond (International capital market Association, 2017).

Kim, M. (2015) it cites up to three potential benefits of issuing green bonds over conventional bonds. The first is a greater diversification of investors, interested in investing in assets that work together in the fight against climate change. The second is that it is an interesting marketing tool for the issuer, which advertise to stakeholders as responsible for the environment. Finally, this author cites studies that indicate that issuing green bonds versus traditional bonds can be more profitable for issuers, thanks to a reduction of up to twenty basis points on the cost of a conventional bond.

The Climate bonds Initiative confirms the benefits listed by Kim, M (2015)., adding that although the issuance of green bonds has additional costs compared to conventional ones such as transactions, revenue tracking, etc., the benefits for issuers outweigh these costs.

Although the green bond market in the European Union accounts for a modest percentage of all issued bonds, this market has attracted a significant public interest, which has served to simplify and standardize the selection process and criteria for environmental projects through more detailed taxonomy, opening the dialog between issuers and investors on criteria and impacts (Clapp, 2018). These taxonomies should be used to design categories of environmental projects which should provide environmentally sustainable direct benefits, which, where possible, will be quantified or evaluated by the issuer (OECD, 2015).

ICMA (2018) classifies green bonds in different types according to the financial structure or legal form as follows:

1. Standard green bond: Is a green bond in which investors resort to the issuer (i.e., in case of default, they could legally act against the issuer, regardless of the 'green' character of the bond).

2. Green revenue Bond: It is a green bond where investors have not resorted to the issuer because they trust the cash-flow generating capacity of green projects for which the emission funds are intended.

3. Green project Bond: Very similar to the previous case, but it is a project-wide bond issue without recourse to the issuer or shareholder.

4. Secure green bond: Is a bond secured by one or more underlying green bond issues, such as covered bonds or other similar structures. 


\section{Findings}

\section{The Green Bond Principles}

The principles of Green bonds are a voluntary, collaborative and consultative guide prepared by the International Capital Market Association (ICMA), which provides guidance for issuing such bonds. These principles involve greater transparency and ease of monitoring of funds, standardization of the practices of both issuers and investors, and support the transition to greater environmental sustainability.

The Green Bond principles are updated annually, adapting to the development of this market. The following summarizes the latest edition, published by ICMA and based on four main components:

1. Use of funds

The Green Bond principles recognize different eligibility categories for green projects and investments, with the aim of addressing various environmental issues. These categories include in particular:

- renewable energies (including production, transmission, devices and products)

- Energy efficiency

- pollution prevention and control

- sustainable management of natural resources and land use

- preserving terrestrial and aquatic biodiversity

- Clean transport

- sustainable management of water and wastewater

- adapting to climate change

2. The project evaluation and selection process

The issuer of a green bond shall disclose to investors:

- environmental sustainability goals.

- the process by which you determine how the green project falls into eligible categories of green projects.

- the associated eligibility criteria and any processes used to identify and manage the social and environmental risks associated with the potential. 
3. Management of funds

Over the lifetime of the bond, the balance of the funds analyzed must be adjusted to match the allocations made to green projects. The issuer will disclose to investors the envisaged types of temporary placement of unallocated funds.

Finally, the principles of Green bonds recommend that the management of the funds be complemented by an auditor or a third party to verify their monitoring and allocation.

4. Publication of reports

Issuers should keep up-to-date information on the use of the funds, such as the projects to which they have been allocated, amounts and expected impact of the funds. It is also recommended to use qualitative indicators and quantitative performance measures and to include in their regular reports the monitoring of the impact achieved.

\section{Evolution of the Green Bond Market}

Since the first issue of green bonds in 2007, growth has been progressive until 2013, when growth has become exponential. In this exercise, multilateral banks joined public organizations and companies, reaching emissions of more than $\$ 10$ billion (World Bank, 2015). Significant volumes of emissions have been observed since 2014. Since then, it has moved from an annual volume of labeled green bond issuance in 2014 of USD 33.000 million to 167.000 million in 2018 (CBI, 2019). Figure 1 shows the historical evolution of green bond emissions.

The green bond market started with self-labeled green bonds, where the issuer (the borrower) simply provided investors with details about the environmental eligibility criteria for the use of the proceeds without any external validation or Regulation. Revenue was primarily earmarked for future renewable energy and energy efficiency projects, thus supporting climate protection. Subsequently, and mainly due to the "green washing", the lack of transparency, doubts about resource allocation and the monitoring of true environmental benefits, it became clear that Regulation was essential (World Bank, 2019).

The annual issuance of green debt instruments has progressively increased since 2011, with a noticeable increase beginning in 2015.

The green debt capital market had just reached a cumulative volume of USD104 billion at the end of 2015. Five years later, in early December, the market topped the cumulative USD1 trillion record, with the year concluding with a USD1.05 trillion total. 
In December 2017, the market for labeled green bonds has a total outstanding value of USD 301 billion. In 2017, green bond issuance was USD 163 billion, an increase of 68 percent over the previous year. Government-related bonds, which include government, national, and supranational agencies, account for $30 \%$ of the total, followed by financial bonds (32\%), and energy company bonds $(21 \%)$. $90 \%$ of the bonds rated by S\&P, Moody's, or Fitch in the complete database are investment-grade, whereas 10\% are high-yield.

The total market size in 2020 indicates a 60 percent annual growth rate from 2015.

Figure 1. Green Issuance 2015-2020

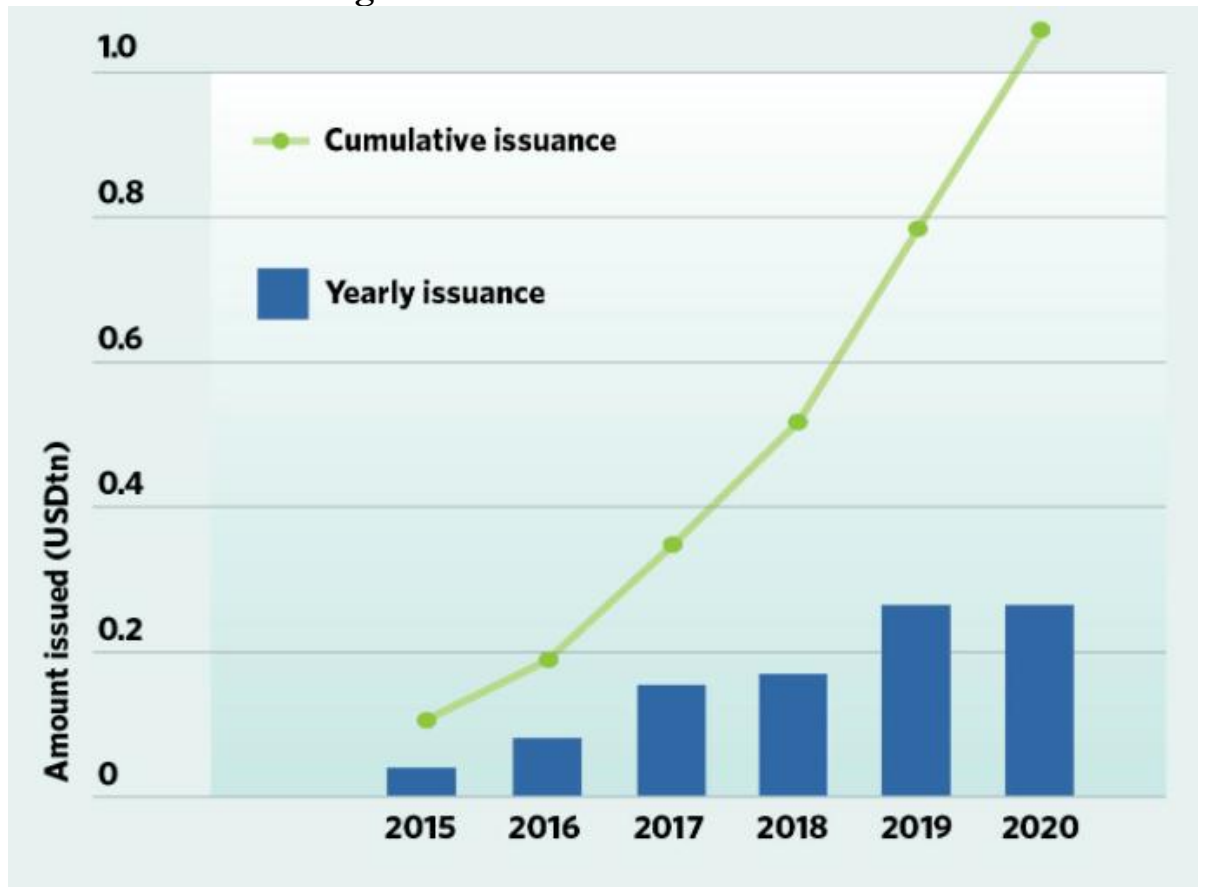

Source: The Climate Bonds Initiative

\section{Review of the EU Green Bond Standards}

The development of the EU Green bond standard (GBS) represents a crucial opportunity to increase the availability of capital to finance the transition to a more sustainable economy and to meet the international commitments made by the European Union. However, while the market is growing, green bonds remain a fraction of the total bond market (less than $4 \%$ of the EU market in 2019) (EC, 2020) mainly due to: (A) the lack of agreement and clarity on what a "green" bond makes; (B) often complex review procedures for green bonds; and (c) lack of projects and investment assets (EC, 2020). 
To ensure a more sustainable financial system, the European Commission has put forward a package of ideas including the creation of a European standard for green bonds certifying that it finances sustainable investments in line with the European Union's environmental ambition. The objective is to have voluntary Regulation providing a model comparable to other market standards, allowing greater transparency toward so-called "green washing" and thus avoid that green financing eventually reaches unsustainable projects. The aim is to mobilize the amount of resources that the EU needs to meet its emission reduction targets. To achieve the target of at least 55\% CO2 reduction by 2030, additional investments of around 350.000 million per year are needed.

The core of this new green bond standard is taxonomy, a herculean classification exercise to distinguish those activities that are truly sustainable. Four requirements are considered in its design, including ensuring that the funds raised are fully allocated to projects complying with the EU taxonomy. Full transparency will also be needed on how the proceeds from the bonds are allocated due to detailed reporting requirements. These European Green bonds will also have strict control mechanisms to ensure that the money is directed to the activities indicated. Their promoters will be required to submit a report before the issue, annual follow-up notes to report how the money collected has been spent and will eventually be subject to review by an external reviewer, supervised by the European Securities markets Authority. Countries' green bonds will benefit from special flexibility. Governments will be able to use public auditors or other public entities for external review, and for some initiatives (such as subsidies for the installation of solar panels) they will not need to show the alignment of each project, but of the program as a whole with the taxonomy.

\section{Green bond trading on the stock exchange}

Stock exchanges play a vital role in providing market access. Markets dedicated to green bonds are essential in their presentation or sustainable bonds. The success of the green bond market in raising capital for the implementation of the 2030 Agenda stimulates a strong interest for as many countries as possible to develop at national level in green bonds that link good international practice to local priorities. Stock markets and regulators have set up working groups and organized working events to clarify certain aspects of green bond markets.

Green bond-financed climate change projects refer in principle to climate change mitigation, resilience and other environmental issues, such as depletion of natural resources, destruction of biodiversity and protection of air, soil or water (Sustainable Banking Network, 2018). 
Figure 2. Stock exchanges that have launched a section dedicated to green or sustainable bonds

\begin{tabular}{|c|c|c|}
\hline Name of Stock Exchange & Type of Dedicated Section & Launch Date \\
\hline Oslo Stock Exchange & Green bonds & January 2015 \\
\hline Stockholm Stock Exchange & Sustainable bonds & June 2015 \\
\hline London Stock Exchange & Sustainable bonds & July 2015 \\
\hline Shanghai Stock Exchange & Green bonds & March 2016 \\
\hline Mexico Stock Exchange & Green bonds & August 2016 \\
\hline Luxembourg Stock Exchange & Luxembourg Green Exchange & September 2016 \\
\hline Borsa Italiana & Green and Social bonds & March 2017 \\
\hline Taipei Exchange & Sustainable bonds & May 2017 \\
\hline Johannesburg Stock Exchange & Green bonds & October 2017 \\
\hline Japan Exchange Group & Green and Social bonds & January 2018 \\
\hline Vienna Exchange & Green and Social bonds & March 2018 \\
\hline Nasdaq (Multiple stock exchanges) & Sustainable bonds & May 2018 \\
\hline Swiss Stock Exchange & Green and Sustainability bonds & July 2018 \\
\hline The International Stock Exchange & Sustainable bonds & November 2018 \\
\hline Frankfurt Stock Exchange & Green bonds & November 2018 \\
\hline Santiago Stock Exchange & Green and social bonds & July 2019 \\
\hline Euronext (Multiple stock exchanges) & Green, Sustainable and Social bonds & November 2019 \\
\hline Bombay Stock Exchange & Green bonds & June 2019 \\
\hline Argentina Stock Exchange BYMA & Green, Sustainable and Social bonds & September 2019 \\
\hline Brazil Stock Exchange & Green bonds & September 2019 \\
\hline Nigerian Stock Exchange & Sustainable bonds & October 2019 \\
\hline Hong Kong Exchange & Green, Sustainable and Social bonds & June 2020 \\
\hline Korea Exchange & Green, Sustainable and Social bonds & June 2020 \\
\hline Toronto Stock Exchange & Sustainable bonds & November 2020 \\
\hline Singapore Stock Exchange & Green, Sustainable and Social bonds & n.a \\
\hline Bolsas y Mercados Españoles (BME) & Green, Sustainable and Social bonds & \\
\hline
\end{tabular}

Source: https://www.climatebonds.net/green-bond-segments-stock-exchanges

Europe dominates the green zone, driven by a wider market for green bonds, which includes many large issuers from both the private and public sectors. AsiaPacific is the largest in the field of social bonds, largely due to heavy pandemic bond issues in China in the first half of 2020. The supranationals form the second largest group in the social field and are the clear leader in sustainability.

Figure 3. Climate Bonds Initiative - Region Green

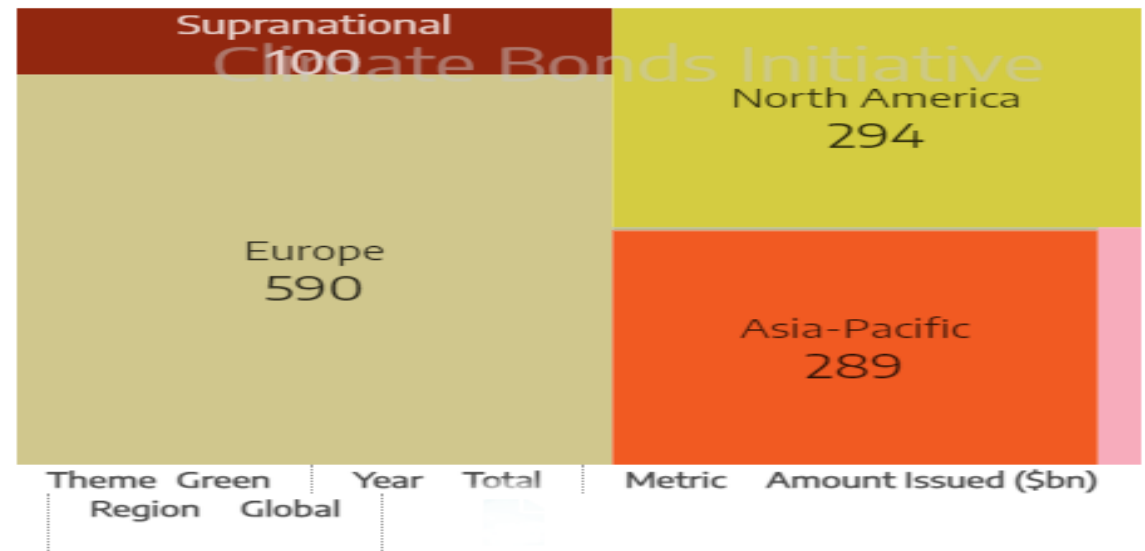

Source: https://www.climatebonds.net/market/data/ 
Nationwide, several companies have started trading in green bonds. Thus, in June 2021, Raiffeisen Bank raised over 1.2 billion lei (288 million dollars / 244 million euros), placing the largest corporate bond issue in lei of an issuer in Romania and the first senior bond issue non-preferential terms of the bank.

The bonds have a maturity of 7 years and will be included in the bank's own funds and on the basis of eligible debts, after prior confirmation of eligibility by the central bank. As the second largest green bond issue in the local market, the company reaffirms its commitment to mobilize financial resources for sustainable purposes and to integrate social and environmental aspects into climate risk management, in order to ensure a progressive decarbonisation of the loan portfolio.

In October 2021, BCR comes to the Bucharest Stock Exchange with its first green bonds, worth 500 million lei. The listing of the first green bonds of BCR comes less than half a year after the listing of the previous bonds, from May 31, amounting to 1 billion lei, the highest from BVB. BCR will thus have available for trading, starting with October 19, three bond issues totaling 2.1 billion lei.

These actions are defined as a responsible business approach and sustainable transformation of the economy, supporting the business environment with information necessary for sustainable development by supporting sustainable initiatives. The company's bond issue is part of BCR's efforts to align with the ESG (Environmental, Social and Governance) criteria, in order to generate sustainable economic development, to encourage environmentally responsible behavior and to reduce social inequalities.

\section{Opportunities created by the COVID-19 pandemic for the development of the green bond market}

The global health crisis that the planet is experiencing due to the coronavirus is strongly felt, and the financing market is once again at the forefront with the issuance of green and sustainable bonds. In the field of sustainable bonds, which unlike green bonds are not intended for the specific financing of environmental projects, the Dutch technology Philips and the American pharmaceutical company Pfizer have emerged successfully. Thus, the additional interest of socially responsible investors for this class of assets, added to the credit quality of issuers and the improvement of the market, as elements that contribute to lowering issuance premiums for green bonds.

However, despite its resistance to the SARS-CoV-2 virus, it is still too early to know whether green bond issues, which in 2019 set a record, will once again peak. 
The trend of launching green and social bonds will continue to grow if volatility remains constant in the emergence of new epidemiological problems.

The financial market is volatile, and the evolution during the pandemic was not the same for all assets. While green bond issues set a new record at $\$ 269.5$ billion (about \$ 221.548 billion), according to data from the Climate Bond Initiative (CBI). According to the report on sustainable financing prepared by the market information platform, CBI, in 2020 the issuance of this class of bonds increased by $756 \%$, reaching 142,200 million dollars $(116,882.7$ million euros), an increase that indicates the effects of the pandemic, which caused the concentration of green bonds to move to some extent towards social bonds, although the level of the latter continues to be higher. Although both types of debt are included in sustainable financing, the big difference between the two is that green bonds are intended to finance projects related to environmental protection, and social bonds are trying to finance projects that alleviate a specific social problem.

By type of issuer, the most active in the field of sustainable debt were governments and supranational organizations, which managed to sell in 2020, sustainable debt for an amount of 250,490 million, 177\% more than in 2019. Behind government issuers there are financial institutions, which have captured, according to the Climate Bond Initiative (CBI), 69,246 million in green bonds and $91,121.5$ million in mixed operations, understood as investments in green and social bonds.

Market operators are optimistic about the future of sustainable debt and the increase in funds they invest based on sustainability criteria. Given the coming months of the IPC, green emissions are expected to reach 370,250 million euros (\$ 450,000 million) by the end of 2021 .

The year 2020 is considered to be a golden one, the COVID-19 pandemic has focused on sustainability through sustainable debt instruments that have raised the funding of many sustainable development projects in recent years. These are crucial elements in the transition to an inclusive, low-carbon economy.

\section{Conclusions}

Green bonds have become an essential instrument for the protection and preservation of the environment, in the field of what is known as sustainable finance, that is, the consideration of environmental and social factors in the decision-making of the companies. The financing that these bonds provide to projects and investments that mitigate climate change such as wind farms, solar panels, energy efficiency, waste management, etc., is essential to reduce CO2 emissions, and replace fossil fuels with renewable energy. 
Green bonds are already a reality in the financial market, with promising prospects in terms of development and volume, and being a key element in the fight against climate change, a problem that affects us all and that it is essential to mitigate. Although green bonds have sometimes been dismissed as a passing fad, it is clear that the market will continue to evolve not only because it is a useful instrument for issuers and investors, but also because climate change and the commitments reached in the Paris Agreement require a continuous effort to support renewable energies and investments that help reduce harmful emissions, these bonds being an interesting option for this. In this way, green bonds are not only an instrument with which to obtain returns, they will also provide a better future for the whole of society.

\section{References}

Arruti, F. J. G., \& Bruzón, A. G. (2018). Bonos verdes y bonos sociales como motores de cambio. Boletín De Estudios Económicos, 73(224), 233-250. Available at: https://www.proquest.com/scholarly-journals/bonos-verdesy-sociales-como-motores-de-cambio/docview/2115668171/se2 ? accountid $=50247$

Baker, Bergstresser, Serafeim y Wurgler, 2018, "Financing the Response to Climate Change: The Pricing and Ownership of U.S. Green Bonds", National Bureau of Economic Research.

CBI (2018). Green bonds: The state of the market 2018. Available at: www.climatebonds.net;

CBI (2019). Green bonds: Global state of the market 2019. Available at: https://www.climatebonds.net/resources/reports/2020;

CBI (2020). Green Bond Market: Summary Q3 2020. Available at: https://www.climatebonds.net/resources/reports/2020;

Clapp, C. (2018): "Investing in a green future". Nature Climate Change, 8 (2), 96.

Cretu, R. F., Cretu, R. C., \& Miron, A. (2014). THE PERFORMANCE OF GREEN ASSETS - A SUSTAINABLE FUTURE: ACCES LA SUCCESS. Calitatea, 15, 106-110. Available at https://www.proquest.com/scholarly-journals/performance-green-assetssustainable-future/docview/1509436328/se-2?accountid $=50247$

Elkington, J. (2013): "Enter the triple bottom line". In The triple bottom line (pp. 23-38). Routledge.

ÍCMA (2017): The Green Bond Principles, Available at: https://www.icmagroup.org/assets/documents/Regulatory/GreenBonds/GreenBondsBrochure-JUNE2017.pdf/

ICMA, 2014-2018, "Green Bond Principles. Voluntary Process Guidelines for Issuing Bonds". 
ICMA, 2018, "Green \& Social Bond Market Update".

Kanamura, T. Are green bonds environmentally friendly and good performing assets?, Energy Econ. (2020), p. 104767. Available at https://www.sciencedirect.com/science/article/pii/S0140988320301079

Kim, M. (2015). Going green: considerations for Green Bonds issuers. Government Finance Review, 31 (6), 14-18.

Le Treut, G., Lefèvre, G., Lallana, F., Bravo, G., 2021. The multi-level economic impacts of deep decarbonization strategies for the energy system. Energy Policy, Volume 156. Available at: https://www.sciencedirect.com/ science/article/pii/S0301421521002937

López y Sebastian, 2015, "Economía y Gestión Bancaria”, Editorial Pirámide.

Mathews y Kidney, 2012, "Financing climate-friendly energy development through bonds", Development Southern Africa (pág. 337-349).

Next Generation EU - Green Bond Framework, COMMISSION STAFF WORKING DOCUMENT, 2021, Bruxelles. Available at: https://ec.europa.eu/info/sites/default/files/about_the_european_comm ission/eu_budget/nextgenerationeu_green_bond_framework.pdf

OECD (2015): Green bonds mobilizing the debt capital markets for a low-carbon transition.

Papadis, E., Tsatsaronis, G., 2020. Challenges in the decarbonization of the energy sector. Energy, Volume 205. Available at: https://www.sciencedirect.com /science/article/pii/S0360544220311324

Rzekęć A, Vial C, Bigot G. Green Assets of Equines in the European Context of the Ecological Transition of Agriculture. Animals. 2020; 10(1):106. Available at https://doi.org/10.3390/ani10010106

Sustainable Debt, Global State of the Market, 2020, Climate Bonds Initiative. Available at: https://www.climatebonds.net/files/reports/cbi_sd_sotm_ 2020_04d.pdf

Sustainable Banking Network (2018). Creating green bond Markets - insights, innovations, and tools from emerging market. Available at: https://www.ifc.org/wps/wcm/connect/37797d8b-c7c1-4361-91831e038b225b5a/SBN+Creating+Green+Bond+Markets+Report+2018.pd $\mathrm{f}$ ?MOD=AJPERES\&CVID $=$ mqtaapI

Zerbib, O.D. The effect of pro-environmental preferences on bond prices: Evidence from green bonds, Journal of Banking \& Finance, Volume 98, 2019, Pages 39-60, ISSN 0378-4266. Available at https://www.sciencedirect.com/science/article/pii/S0378426618302358. 